\title{
Study on land use change and its impact on ecosystem service value -Taking Hengyang central district for example
}

\author{
Fuqiang Huang ${ }^{l}$, Zengxiang $Q i^{1}$, \\ ${ }^{1}$ School of Architecture, University of South China, 421001 Hengyang, China
}

\begin{abstract}
Land use change on ecosystem service value(ESV) and its interaction is significant in the rapid urbanization. The GIS(Geographic Information System) incorporating with ESV equivalent factor is used to quantitatively study the change of land use change and its impact on the ecosystem service value in Hengyang central district. Further more, the Markov model is used to predict the change of land use and ESV in 2030 under the scenario of historical trend development. The results can serve as a useful tool that assists urban planners in their evaluation of ecosystem service value under the impact of land use change.
\end{abstract}

\section{INTRODUCTION}

Ecosystem service is the natural environmental condition of human existence and development formed by ecosystem in the ecological process ${ }^{[1]}$, Whose's value can provide scientific basis for human beings to improve the quality of life and production ${ }^{[2]}$. Land use cover/change (LUCC) is the main cause of global environmental change ${ }^{[3]}$, which plays a decisive role in the change of ecosystem service. In the process of rapid urbanization, the improper use of land by human beings has led to the increasing impact of ecological environment such as water quality purification ${ }^{[4]}$, soil conservation $^{[5]}$, biodiversity ${ }^{[6]}$, nutrient cycle ${ }^{[7]}$, climate regulation $^{[8]}$ and et al. As a result, the function of ecosystem services are weakened and degraded, which seriously affects the balance of regional ecosystems. The urban central district is the core area of urban development, where the pressure of resources and environment is becoming more and more prominent. So it is important to study on the land use change and its impact on ESV in urban central district. In this study, the characteristics of land use and ESV dynamic change in urban central district are revealed based on the LandSatTM data incorporated with ESV equivalent factor in GIS. Futher more, the Markov model is used to predict the change of land use and ESV in 2030. The results can serve as a useful tool that assists urban planners in their evaluation of ESV under the impact of land use change.

\section{METHODOLOGY}

\subsection{Markov model}

Markov model, which is a special stochastic movement process just like the process of dynamic change of land use is often used to predict the quantitative change of land use ${ }^{[9]}$. It is defined as follows:

$$
S(n)=S(n-1) P_{i j}
$$

Where, $S(n)$ and $S(n-1)$ is the state of the system at the time $\mathrm{n}$ and $\mathrm{n}-1$ respectively; $P_{i j}$ is the transition probability matrix, which defined as follows:

$$
A_{i j}=\left[\begin{array}{cccc}
A_{11} & A_{12} & \ldots & A_{1 n} \\
A_{21} & A_{22} & \ldots & A_{2 n} \\
\vdots & \vdots & \vdots & \vdots \\
A_{n 1} & A_{n 2} & \ldots & A_{n n}
\end{array}\right]
$$

Where, $A_{i j}$ is the area of land use $\mathrm{i}$ to land use $\mathrm{j}, \mathrm{i}$ is the initial land use category, $\mathrm{j}$ is the land use category at the end of the study period, the row represents the direction of land use conversion, the column represents the source of land use conversion. There are two rules in the $P_{i j}$.

$$
\sum_{\mathrm{j}=1}^{\mathrm{n}} P_{i j}=1(\mathrm{i}, \mathrm{j}=0,1,2 \ldots \ldots, \mathrm{n})
$$

Where, the sum of elements per row of a matrix is equal to 1 .

$$
0 \leq P_{i j} \leq 1(\mathrm{i}, \mathrm{j}=0,1,2 \ldots \ldots, \mathrm{n})
$$

Where, each element of the matrix is not negative.

\subsection{Ecosystem service value evaluation}

The ESV equivalent factor is the relative contribution rate of ecosystem-generated services, which is equal to $1 / 7$ of the national average grain yield market price of the year ${ }^{[10,11]}$. It is defined as follows:

$$
V C_{0}=\frac{1}{7} \times P \times Q
$$

Where, $V C_{0}$ is the ESV equivalent factor $\left(¥ \cdot \mathrm{hm}^{-2}\right), \mathrm{P}$ is the national average grain price $\left(¥ \cdot \mathrm{kg}^{-1}\right), \mathrm{Q}$ is the national average grain yield $\left(\mathrm{kg} \cdot \mathrm{hm}^{-2}\right)$.

The formula for calculating ESV is defined as follows:

\footnotetext{
* Corresponding author: qizengxiang@126.com
} 


$$
\begin{aligned}
& \mathrm{ESV}=\sum_{i=1}^{n}\left(A_{i} \times V C_{i}\right) \\
& \mathrm{ESVf}=\sum A_{i} \times V C_{f i}
\end{aligned}
$$

Where, ESV is the value of ecosystem services $(¥), A_{i}$ is the area of I-th land use type $\left(\mathrm{hm}^{2}\right), V C_{i}$ is the total value of ecosystem service function per unit area of land use type( $¥ \cdot \mathrm{hm}^{2}$.year), ESVf is the value of the $\mathrm{f}$-th service function of the ecosystem( $¥), V C_{f i}$ is the total value of the $\mathrm{f}$-th ecosystem service function per unit area of land use type (¥·hm².year).

The ESV equivalent factor of Construction land is refer to the study of Zheng $\mathrm{J} \mathrm{K}^{[2]}$. Table 1 shows the ESV per unit area of different landscape types.

Table 1. The ESV per unit area of different land use.

\begin{tabular}{ccc}
\hline Land use & $\begin{array}{c}\text { Equivalent } \\
\text { factor }\end{array}$ & ESV $\left(¥ \cdot \mathrm{hm}^{-2}\right)$ \\
\hline Cultivated land & 3.95 & 11141.51 \\
Forest land & 23.09 & 65128.49 \\
Grassland & 15.56 & 43889.10 \\
Water area & 125.61 & 354300.13 \\
Construction & & \\
land & -6.64 & 18735.42 \\
Unused land & 0.65 & 1833.41 \\
\hline
\end{tabular}

\section{STUDY AREA AND DATASETS}

Hengyang city is located in the south-central part of Hunan Province $\left(110^{\circ} 32^{\prime} 16^{\prime \prime}-113^{\circ} 16^{\prime} 32^{\prime \prime}\right)$, which is an sub-center city and important industrial city of Hunan Province. Hengyang city plays a regional central role in Changsha-Zhuzhou-Xiangtan urban agglomeration and Xiangnan area, which shoulders the heavy responsibility of promoting the development of the southern Hunan region. The study area of this paper is the central area of Hengyang city, including Shigu District, Yanfeng District, Zhuhui District and Zhengxiang District.

To analyze how land use change will affect ecosystem service value, historial land-use patterns from 2000, 2010(Figure 1) are used in this study.
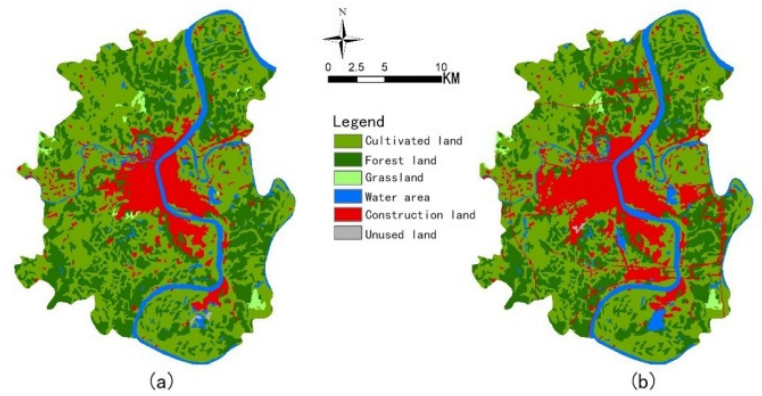

Fig. 1. Land use of Hengyang central district. (a)2000; (b)2010.

\section{LAND USE CHANGE AND CONVERTION DURING 2000-2010}

\subsection{Land use change}

Table 2 shows the change of land use in Hengyang central district from 2000-2010. The cultivated land, forest land, water area and construction land were the most important land use types in Hengyang central district. During 2000-2010, the amount of land use changed to varying degrees that the area of cultivated land and forest land decreased greatly, while the construction land increased greatly. The cultivated land was the land type with the largest decrease, which decreased by $2277.63 \mathrm{hm}^{2}$ and change rate of $8.69 \%$ in 11 years. The forest land, which decreased the change rate of $1384.02 \mathrm{hm}^{2}$, by $9.32 \%$ in 11 years. The third was grassland, which decreased the change rate of 103.05 $\mathrm{hm}^{2}$, by $21.22 \%$ in 11 years. Finally, the change rate of $16.92 \mathrm{hm}^{2}$ in unused land decreased by $30.62 \%$ in 11 years. It could be seen that a large number of cultivated land and forest land had been transformed into construction land to meet the needs of urban development. The construction land was the largest range land use, whose change rate of $3520.26 \mathrm{hm}^{2}$ and had been increased by $56.94 \%$ in the past 11 years. The change range of water area was small during the study period, whose area increased by $261.36 \mathrm{hm}^{2}$ and the change rate of $7.16 \%$.

\begin{tabular}{|c|c|c|c|c|c|c|}
\hline \multirow[b]{2}{*}{$\begin{array}{l}\text { Land } \\
\text { use }\end{array}$} & \multicolumn{2}{|c|}{2000} & \multicolumn{2}{|c|}{2010} & \multicolumn{2}{|c|}{ Change } \\
\hline & $\begin{array}{l}\text { Area/ } \\
\mathrm{hm}^{2}\end{array}$ & $\begin{array}{l}\mathrm{pr} \\
\text { op } \\
\text { ort } \\
\text { ion } \\
/ \%\end{array}$ & $\begin{array}{l}\text { Area } \\
/ \mathrm{hm}^{2}\end{array}$ & $\begin{array}{l}\mathrm{pr} \\
\text { op } \\
\text { ort } \\
\text { ion } \\
/ \%\end{array}$ & $\begin{array}{c}\text { devia } \\
\text { tions } \\
/ \mathrm{hm}^{2}\end{array}$ & $\begin{array}{c}\text { ran } \\
\text { ge } \\
/ \%\end{array}$ \\
\hline $\begin{array}{l}\text { Cultiva } \\
\text { ted }\end{array}$ & 2620 & 50. & 2392 & 46. & $\begin{array}{c}- \\
2277\end{array}$ & 8.69 \\
\hline land & 6.38 & 95 & 8.75 & 52 & $\begin{array}{c}.63 \\
-\end{array}$ & \\
\hline $\begin{array}{c}\text { Forest } \\
\text { land }\end{array}$ & $\begin{array}{l}1485 \\
1.71\end{array}$ & $\begin{array}{l}28 . \\
88\end{array}$ & $\begin{array}{l}1346 \\
7.69\end{array}$ & $\begin{array}{l}26 . \\
18\end{array}$ & $\begin{array}{c}1384 \\
.02\end{array}$ & 9.32 \\
\hline $\begin{array}{c}\text { Grassl } \\
\text { and }\end{array}$ & $\begin{array}{c}485.6 \\
4\end{array}$ & $\begin{array}{c}0.9 \\
4\end{array}$ & $\begin{array}{c}382 . \\
59\end{array}$ & $\begin{array}{c}0.7 \\
4\end{array}$ & $\begin{array}{c}- \\
103 . \\
05\end{array}$ & $\begin{array}{c}21.2 \\
2\end{array}$ \\
\hline $\begin{array}{c}\text { Water } \\
\text { area }\end{array}$ & $\begin{array}{c}3651 . \\
84\end{array}$ & $\begin{array}{c}7.1 \\
0\end{array}$ & $\begin{array}{c}3913 \\
.20\end{array}$ & $\begin{array}{c}7.6 \\
1\end{array}$ & $\begin{array}{c}261 \\
36\end{array}$ & 7.16 \\
\hline $\begin{array}{c}\text { Constr } \\
\text { uction } \\
\text { land }\end{array}$ & $\begin{array}{c}6182 . \\
19\end{array}$ & $\begin{array}{l}12 . \\
02\end{array}$ & $\begin{array}{c}9702 \\
.45\end{array}$ & $\begin{array}{l}18 . \\
86\end{array}$ & $\begin{array}{c}3520 \\
.26 \\
-\end{array}$ & $\begin{array}{c}56.9 \\
4\end{array}$ \\
\hline $\begin{array}{l}\text { Unuse } \\
\mathrm{d} \text { land }\end{array}$ & 55.26 & $\begin{array}{c}0.1 \\
1\end{array}$ & $\begin{array}{c}38.3 \\
4\end{array}$ & $\begin{array}{c}0.0 \\
7\end{array}$ & $\begin{array}{c}16.9 \\
2\end{array}$ & $\begin{array}{c}30.6 \\
2\end{array}$ \\
\hline
\end{tabular}

Table 2. The change of land use from 2000-2010.

\subsection{Land use convertion}

Table 3 shows the convertion of land use during 20002010. There were four main types of conversion in the central district: the cultivated land, forest land, grassland and water area converted into the construction land, whose area were $2264.22 \mathrm{hm}^{2}, 1391.85 \mathrm{hm}^{2}, 57.15 \mathrm{hm}^{2}$ and $91.89 \mathrm{hm}^{2}$ respectively; the forest land, water area and construction land converted into the cultivated land, whose area were $415.35 \mathrm{hm}^{2}, 154.62 \mathrm{hm}^{2}$, and 249.39 $\mathrm{hm}^{2}$ respectively; the cultivated land, water area were 
converted into the forest land, whose area were 425.61 $\mathrm{hm}^{2}$ and $60.84 \mathrm{hm}^{2}$ respectively.

Table 3. The land use convertion during 2000-2010

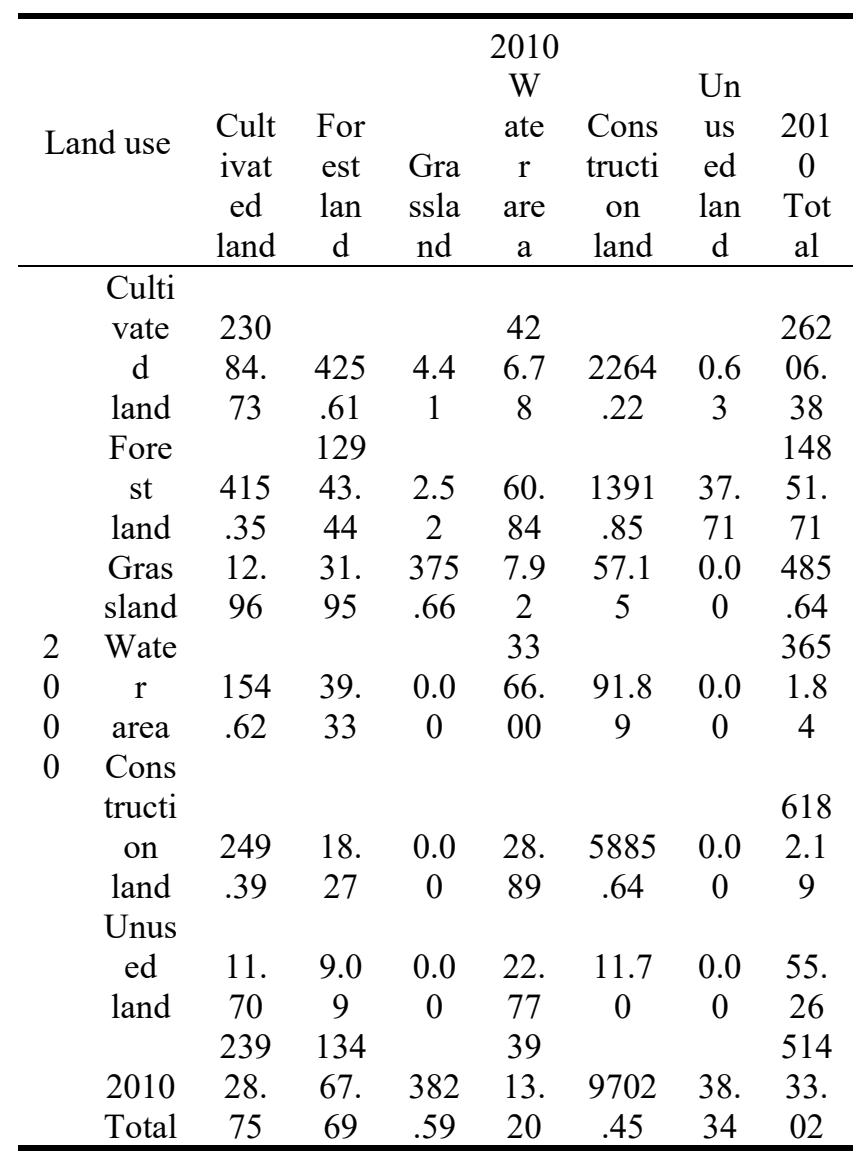

\section{ECOSYSTEM SERVICES VALUES CHANGE AND PREDICTION}

\subsection{Ecosystem services values change}

Table 4 shows the change of ESV caused by LUCC. Forest land, water area and cultivated land were the land use which contributed the most to the ESV of the central district. The ESV decreased from $24.59 \times 10^{8} ¥$ to $23.65 \times 10^{8} ¥$, which decreased by $3.8 \%$ during 2000 to 2010.The main reasons for the decrease of ESV were the rapid decrease of ESV of cultivated land and forest land. Furthermore, the increasing negative effect of construction land on ESV was becoming more and more prominent. The total ESV of cultivated land reduced by $0.25 \times 10^{8} ¥$ due to the encroachment of construction land and the conversion of cultivated land to forestland. The total ESV of forest land is reduced by $0.9 \times 10^{8} ¥$ due to the deforestation and cultivation of forest land and the encroachment of construction land. The development of social economy and city in Hengyang City leads to the rapid expansion of construction land, which makes the annual change rate of ESV of construction land as high as $56.94 \%$ that indicates that the negative effect of construction land on the ESV of the region is becoming worse. The ESV of water area showed an increasing trend. Because Xiangjiang River, Lei water, Steamed water and other reservoirs accounted for a certain proportion of the total land use area and per unit area of ESV was the highest. Although the ESV of grassland and unused land varied greatly, it had a small impact on the regional ESV for it's low proportion of the total land use.

Table 4. The change of ESV caused by LUCC from 2000-2010.

\begin{tabular}{cccc}
\hline Land use & \multicolumn{2}{c}{$\mathrm{ESV} / 10^{8} ¥$} & $\begin{array}{c}\text { Change of } \\
\text { ESV } / 10^{8} ¥\end{array}$ \\
\cline { 2 - 3 } & 2000 & 2010 & -0.25 \\
\hline $\begin{array}{c}\text { Cultivated } \\
\text { land }\end{array}$ & 2.92 & 2.67 & -0.90 \\
Forest land & 9.67 & 8.77 & -0.05 \\
Grassland & 0.21 & 0.17 & 0.93 \\
Water area & 12.94 & 13.86 & -0.66 \\
$\begin{array}{c}\text { Construction } \\
\text { land }\end{array}$ & -1.16 & -1.82 & 0.00 \\
$\begin{array}{c}\text { Unused land } \\
\text { Total }\end{array}$ & 0.00 & 0.00 & -0.93 \\
\hline
\end{tabular}

\subsection{Prediction of ecosystem services values in 2030}

Table 5 shows the Prediction of land use and ESV by Markov model in 2030. It can be seen that the area of construction land and water area will increase from $18.86 \%$ to $29.76 \%$ and $8.33 \%$ to $29.76 \%$ respectively, while the cultivated land, forest land, grassland and unused land will decrease from $46.52 \%, 26.18 \%, 0.74 \%$ and $0.07 \%$ to $39.76 \%, 21.62 \%, 0.47 \%$ and $0.06 \%$ in 2030 respectively. It shows that the contradiction between the development of construction land and the protection of ecological land in central district will be further intensified and the corresponding ecological land protection will face severe challenges with the rapid development of the urban,. The total ESV will continue to decline from $23.65 \times 10^{8} ¥$ to $21.94 \times 10^{8} ¥$. The decrease of ESV of cultivated land and forest land and the aggravation of the negative effect of construction land on ESV are the main reasons for the decrease of the total ESV in central district in the future, Cultivated land and forest land are the land with the greatest change in ESV. The ESV of water area and construction land show a slow growth trend, while the ESV of grassland and unused land change little.

Table 5. Prediction of land use and ESV in 2030

\begin{tabular}{ccc}
\hline Land use & Area $/ \mathrm{hm}^{2}$ & $\mathrm{ESV} / 10^{8} ¥$ \\
\hline Cultivated land & 20451.06 & 2.28 \\
Forest land & 11122.29 & 7.24 \\
Grassland & 239.58 & 0.11 \\
Water area & 4284.27 & 15.18 \\
Construction & & \\
land & 15304.14 & -2.87 \\
Unused land & 31.59 & 0.00 \\
Total & 51432.93 & 21.94 \\
\hline
\end{tabular}




\section{CONCLUSION AND DISCUSSION}

This paper studies the ESV based on land use change in the Hengyang central district.The main conclusions are as follows:

(1) The land use in Hengyang central district was mainly based on cultivated land, forest land, water area and construction land during 2000 to 2010 . The land use types were varying degrees of change, which mainly reflected in the rapid increase of construction land and large decrease of cultivated land and forest land.

(2) The cultivated land and the forest land were the land with the largest transfer area. The forest land was mainly converted into the cultivated land, while the construction land and cultivated land was mainly converted into the forest land, construction land and water area. The construction land would be dominant in future changes. The water area was slowly increasing, while the transfer-out area of the grassland and the unused land changed little.

(3) The ESV changed from $24.59 \times 10^{8} ¥$ to $23.65 \times 10^{8}$ $¥$ during 2000 to 2010 . Forest land and water area were the land with the highest contribution rate to ESV. The area of cultivated land, forest land, grassland and unused land will decline, while the construction land and water area will rise in the 2030. In 2030, the ESV of central district will be $21.94 \times 10^{8} ¥$, which is $1.71 \times 10^{8} ¥$ lower than that in 2010 .

In this study, the precision of Landsat ETM data had a certain impact on the the total ESV. In the future study, we should consider using high-definition images to interpret and classify the land types in detail in order to obtain more accurate of land use change and ESV. In the prediction of land use change in 2030, we did not consider planning policies which would have a definite impact on judging the real change of ESV in Hengyang central district. Thus, study of the prediction under multi-scenario will need to be strengthened in the future.

\section{References}

1. Wu J S, Mao J Y, Lin Q, et al. Urban growth boundary based on the evaluation of habitat quality: Taking the Yangtze river delta as an example[J]. Scientia Geographica Sinica, 2017,37(01): 28-36.

2. Zheng J K, Yu X X, Jia G D, et al. Dynamic evolution of the ecological service value based on LUCC in Miyun Reservoir Catchment[J]. Transactions of the CSAE,2010, 26(09): 315-320.

3. Liu Y S, Chen B M. The study framework of land use /cover change based on sustainable development in China[J]. Geograph Ical Research, 2002, 21(03): 324-330.

4. Zhang K, Ran S H, Tian Y J, et al. Influence of oasis urban expansion on water resources in arid areas:a case study for Shihezi city[J]. Resources Science, 2011, 33(09): 1720-1726.

5. Wu S H, Zhou S L, Pan H Z, et al. Quantitative partitioning of impacts of urban sprawl process on heavy metal accumulation in Yixing,China[J]. Acta Pedologica Sinica, 2011, 48(03): 496-505.

6. Wang Q, Ruan J J, Sha C Y, et al. Human impacts on the spatial pattern of biodiversity of Shanghai City [J]. Ecology and Environmental Sciences, 2012, 21(02): 279-285.

7. Li C G. Study on spatial variability of soil nutrient in typical urban-rural ecotone of Wuhan based on GIS[D]. Huazhong Agricultural University, 2009.

8. Shao N P, Liu X P, Qu X Y. Valuation of lake wetland ecosystem services of Yinchuan City[J]. Chinese Journal of Ecology, 2008, 27(9): 1625-1630.

9. Zhou R, Su H L, Wang X J, et al. Simulation of land use change in Xinzhuang town under different scenarios based on the CLUE-S model [J]. Resources Science, 2011, 33(12): 2262-2270.

10. Xie G D, Zhang $C \mathrm{X}$, Zhang $\mathrm{L} \mathrm{M}$, et al. Improvement of the Evaluation Method for Ecosystem Service Value Based on Per Unit Area [J]. Journal of Natural Resources, 2015, 30(08): 1243-1254.

11. Xie G D, Xiao Y, Zhen L, et al. Study on ecosystem services value of food production in China [J]. Chinese Journal of Eco-Agriculture, 2005, 13(03): 10-13. 